\title{
SISTEM MAPARO SEBAGAI SOLUSI PENINGKATAN PEREKONOMIAN MASYARAKAT EKONOMI SYARIAH (MES) DI ERA 4.0
}

\author{
Muallifatur Rosidah* \\ *Magister Ekonomi Syariah \\ Universitas Islam Negeri Profesor Kiai Haji Saifuddin Zuhri Purwokerto \\ Email : muallifaturrosidah2015@gmail.com
}

\begin{abstract}
Abstrak : Sistem maparo dalam bisnis yang ada pada peternakan kambing yang dapat meningkatkan ekonomi masyarakat, khusunya masyarakat Muslim yang ada di Desa Sadabumi Kecamatan Majenang Kabupaten Cilacap, menggunakan transaksi kerjasama yakni "mudharabah" istilah lokalnya adalah akad maparo. Akad/transaksi maparo sendiri diartikan sebagai sistem bisnis dalam bidang peternakan, dimana para produsen/peternak yang melakukan bisnis dilakukan bersama-sama dengan pihak pemilik modal. Investasinya yakni berupa kambing, selanjutnya produk kambing ini ketika sudah layak jual (dewasa) kemudian hasil dari produk yang dijual ini akan dibagi dengan pihak si pemilik modal (bagi hasil). Penelitian ini dilakukan di Desa Sadabumi, Majenang, Cilacap. Dimana peneliti terjun langsung kelapangan untuk meneliti, kemudian hasil penelitian berupa pendeskripsian yang ada di lapangan. Teknik pengumpulan data dalam riset ini yakni teknik observasi dan wawancara serta dokumentasi. Hasil Penelitian membuktikan bahwa dalam bisnis melalui sistem maparo ini masuk bisnis dengan sistem mudharabah-muqayyadah. Dalam sistem maparo bisnis ini para pihak produsen dan pembeli tidak hanya dijadikan sebuah bisnis semata, melainkan tujuan maparo ini selain untuk bisnis adalah untuk menjalin hubungan silaturrahmi (persaudaraan) antar sesama muslim yang mana di era 4.0 Sistem bisnis maparo juga menjadi salah satu sistem pengembangan usaha bagi pemilik modal. Akad mudharabah muqayyadah dalam sistem maparo merupakan manivestasi dari prinsip-prinsip dalam bisnis syariah, hal ini dikarenakan tujuan dari permodalan dalam bisnis ini yakni al-Ta'awun (tolong-menolong), keadilan dalam transaksi bagi hasil, dan prinsip berbagi resiko dalam kerugian yang terjadi selama bisnis yang telah terjalin.
\end{abstract}

Kata Kunci : Sistem Maparo, Masyarakat Ekonomi Syariah, Era 4.0 


\section{PENDAHULUAN}

Target pertumbuhan ekonomi yang diasumsikan oleh kementerian keuangan pada Anggaran Pendapatan Belanja Negara (APBN) 2020 masih belum sesuai dengan harapan dan citacita ekonomi yang maju, meskipun masih ada waktu untuk memperbaikinya di kuartal IV 2020, namun kita harus menerima fakta di lapangan bahwa dalam tiga tahun terakhir ekonomi Indonesia tidak pernah sekalipun berhasil mencapai target pertumbuhan ekonomi yang dicanangkan oleh kebijakan pemerintah.

Sudah saatnya desentralisasi ekonomi dijalankan dengan serius, karena ini bisa menjadi solusi dari lambatnya pertumbuhan ekonomi Indonesia saat ini. Kegiatan usaha dan bisnis desa bisa menjadi strategi dalam peningkatan pertumbuhan ekonomi desa sesuai yang dicanangkan oleh Kementerian Desa, Pembangunan Daerah Tertinggal dan Trasnmigrasi (PDTT) (Iskandar, 2021). Dengan begitu perekonomian desa bisa diandalkan dalam menopang dan membantu ekonomi masyarakat desa itu sendiri.

Regulasi turunan terkait Undangundang Cipta Kerja misalnya dengan membolehkan Badan Usaha Milik Desa (BUMDES) mengelola usaha sumber daya air, serta bagian dari pada (jalan tol serta non-tol) yang diatur dalam peraturan pemerintah sebagaimana termaktub pada PP. No.5/ 2021. Merujuk pula pada PP Nomor 30 tahun2021, Badan Usaha Milik Desa (BUMDES) boleh bekerja sama dalam pengujian kendaraan bermotor, kalibrasi hingga jasa pemeliharaan. Adapun Berdasarkan data Badan Pusat Statistik (BPS) terdapat 83.931 wilayah administrasi setingkat desa di Indonesia pada tahun 2018 (Badan Pusat Statistik, 2018). Dari jumlah desa tersebut, setiap desa pasti memiliki potensi ekonomi yang berbeda-beda untuk bisa dikembangkan secara maksimal. Salah satu kegiatan usaha yang bisa ditemukan dan memang cocok untuk dikembangkan di wilayah pedesaan adalah berwirausaha di bidang peternakan.

Peternakan adalah usaha pemeliharaan dan pembiakan ternak untuk mendapatkan keuntungan ekonomi. Area pedesaan didukung faktor lahan yang masih luas, mudah menemukan pakan, dan masih tersedianya sumber daya masyarakat yang bersedia menjadi peternak. Berdasarkan hasil observasi yang dilakukan oleh peneliti di Desa Sadabumi Kecamatan Majenang Kabupaten Cilacap merupakan desa yang asri dan sangat strategis untuk melakukan kegiatan usaha, khususnya di bidang peternakan kambing. Dengan total luas wilayah sejumlah 1.001 ha, dengan lahan perkebunannya mencapai hingga 183 ha serta lahan hutannya adalah 454 ha, sehingga lahan tersebut dapat dijadikan sebagai penyedia pakan dan tempat beternak.

Kemudian dari jumlah penduduk sebanyak 5.392 orang, yang memiliki mata pencaharian sebagai petani yakni sejumlah 2.283 orang. Keadaan geografis dan daya dukung sumber daya manusia tidak serta merta memudahkan praktek usaha peternakan kambing. Peternak masih terbentur kurangnya modal untuk membeli bibit kambing. Dalam ekonomi Islam, kekurangan modal semacam ini diberikan beberapa alternatif, salah satunya adalah Mudharabah.

Dalam hal ini peneliti menemukan bahwa praktek mudharabah yang sudah lama terjalin sampai menjadi tradisi/adat ini telah dilakukan oleh masyarakat ekonomi syariah (yakni masyarakat Muslim yang ada di Desa Sadabumi Kecamatan Majenang Kabupaten Cilacap, Provinsi jawa tengah), yang mana dalam tradisi maparo ini adalah terkait peternakan kambing, dengan menggunakan sistem kerjasama tersebut. 
Cara atau trik model sistem kerjasama ini adalah dimulai dari para pemilik modal yang menanamkan modalnya dalam bentuk hewan kambing kepada peternak untuk dikembang-biakan hingga mendapatkan keuntungan dikemudian hari. Sesuai tradisi yang ada, semua kebutuhan ternak menjadi tanggung jawab pemelihara ternak. Selama merawat hewan ternak tersebut, peternak tidak memperoleh bayaran atau upah apapun.

Di setiap daerah sistem maparo memiliki nama yang berbeda, misalnya saja istilahtenar/viral yang ada di Kabupaten Purworejo dinamakan "Nggado", istilah kerjasaman "Belah" yang biasa digunakan mayarakat ekonomi syariah di era 4.0 seperti sekarang ini yakni di Kabupaten Lubuhanbatu Provinsi Sumatera Utara (Khairudin, 2010). Namun dalam sistem bagi hasil ini dalam hal keuntungannya sama, yakni laba yang telah didapatkan oleh para kedua belah pihak adalah dengan ditentukan sejak awal akad yakni dengan nisbah bagi hasil dibagi dua sama rata dari hasil penjualan ternak setelah dikurangi harga beli.

\section{TINJAUAN PUSTAKA}

\section{Sistem Maparo Sebagai Alternatif Usaha Rakyat di Era 4.0}

Maparo masih sanggup eksis tidak hilang ditelan zaman karena berbasis kearifan lokal walaupun memang sudah berkurang peminatnya. Namun tidak menutup kemungkinan usaha peternakan kambing dengan sistem maparo akan berkembang lebih baik lagi jika pemerintah mendukung sepenuhnya program pengembangan peternakan rakyat ini. Salah satu cara yang bisa dilakukan oleh pemerintah adalah dengan menyediakan modal bibit ternak unggul untuk dikembangkan peternak, memberikan edukasi dan pelatihan ternak modern. Sistem kerjasamanya masih menggunakan sistem maparo dimana pemerintah menjadi shohibul maal dan peternaknya menjadi mudhorib. Secara umum kerjasama maparo dirasa belum mampu meningkatkan kesejahteraan masyarakat khususnya pemilik modal dan pemelihara ternak. Maparo menjadi salah satu cara investasi bagi pemilik modal, dan menjadi mata pencaharian lain bagi pemelihara ternak untuk memperoleh penghasilan tambahan.

\section{Sistem Maparo sebagai Solusi bagi Perekonomian Masyarakat Ekonomi Syariah di Era 4.0}

Dalam rangka usaha dalam meningkatkan ekonomi masyarakat ekonomi syariah di era 4.0 melalui sistem maparo dimana era revolusi 4.0 menjadi tantangan tersendiri bagi Indonesia dalam mensejahterahkan ekonomi masyarakatnya perlu adanya trik market tersendiri salah satunya dengan mengembangkan ekonomi syariah Indonesia.Dengan adanya respon dari dunia barat serta sumbangsih barat terhadap ekonomi syariah Indonesia dimaksudkan untuk merangkul ekonomi syariah Indonesia dengan tujuan utamanya adalah menguasai Indo Pasifik, dengan menerapkan sebuah trik market dalam sistem pasar bebas dan juga sistem kapitalis. Namun Indonesia tetap pada prinsipnya yaitu mengembangkan potensi ekonomi syariah, yang mana hal ini dikarenakan ekonomi syariah di Indonesia merupakan sebuah peluang emas dalam menuju Indonesia yang sejahtera.

Selain itu ada dua sistem dalam meningkatkan ekonomi masyarakat ekonomi syariah di era 4.0 melalui sistem maparo dimana era revolusi 4.0 diantaranya melalui penerapan sistem bagi hasil dalam praktik maparodan menerapkan prinsip yang ada pada ekonomi syariah tentang (al-ta'awun) atau prinsip tolong-menolong yang 
terkandung dalam kerjasama maparo.

\section{METODE PENELITIAN}

$$
\text { Penelitian ini merupakan }
$$

penelitian deskriptif kualitatif. Peneliti mengamati secara langsung terkait aktivitas bisnis dengan menggunakan "sitem maparo" oleh masyarakat Muslim di Desa Sadabumi Kecamatan Majenang Kabupaten Cilacap Provinsi jawa Tengah. Adapun teknik pengumpulan data yang digunakan yaitu observasi, wawancara, dan pendokumentasian (Arikunto, 2010).

\section{HASIL DAN PEMBAHASAN}

Hasil kerjasama maparo bagi masyarakat ekonomi syariah di era 4.0 yang ada di Desa Sadabumi, bukan semata-mata kerjasama bisnis, namun juga salah satu cara menjalin silaturahmi dan merekatkan rasa persaudaraan. Jika kerjasama hanya dilandaskan pada prinsip mencari keuntungan, kerjasama maparo kambing ini kurang menjanjikan. Bagi hasil yang diperoleh cukup kecil, dan tidak cukup memenuhi kebutuhan keluarga sepenuhnya. Jangka waktu pemeliharaan ternak untuk sampai dijual juga lama, sehingga pemilik modal harus menunggu sekitar delapan bulan untuk perputaran modalnya. Resiko kematian kambing ditanggung bersama antara pemilik modal dengan pemelihara ternak, namun jumlahnya berbeda. Jika terjadi kematian ternak, pemilik modal kehilangan modal beli indukan kambing sedangkan bagi peternak kehilangan upah kerja yang telah dia lakukan selama merawat kambing tersebut.

Namun di sisi lain ternak kambing dianggap sebagai pekerjaan yang kasar/kotor dan kurang milenial sehingga hanya diminati oleh orang-orang lanjut usia atau masyarakat dengan usia diatas 45 tahun. Generasi muda lebih memilih pekerjaan yang dianggap bersih dan memiliki nilai gengsi tinggi seperti penjahit konveksi, jual voucher internet, sopir travel dan merantau ke kota-kota besar seperti halnya Ibu Kota Jakarta dan Ibu Kota Jawa barat yakni Kota Bandung.

\section{Sistem Maparo Sebagai Alternatif Usaha Rakyat di Era 4.0 \\ Maparo masih sanggup eksis tidak} hilang ditelan zaman karena berbasis kearifan lokal walaupun memang sudah berkurang peminatnya. Namun tidak menutup kemungkinan usaha peternakan kambing dengan sistem maparo akan berkembang lebih baik lagi jika pemerintah mendukung sepenuhnya program pengembangan peternakan rakyat ini. Salah satu cara yang bisa dilakukan oleh pemerintah adalah dengan menyediakan modal bibit ternak unggul untuk dikembangkan peternak, memberikan edukasi dan pelatihan ternak modern.

Sistem kerjasamanya masih menggunakan sistem maparo dimana pemerintah menjadi shohibul maal dan peternaknya menjadi mudhorib. Secara umum kerjasama maparo dirasa belum mampu meningkatkan kesejahteraan masyarakat khususnya pemilik modal dan pemelihara ternak. Maparo menjadi salah satu cara investasi bagi pemilik modal, dan menjadi mata pencaharian lain bagi pemelihara ternak untuk memperoleh penghasilan tambahan.

Misalnya Bapak Wawien seorang warga RT 001 RW 001 yang berdomisili di Desa Sadabumi, beliau profesi utamanya yaitu sebagai penjahit. Hal inilah yang membuat dan mendorong warga untuk mendapatkan penghasilan tambahan untuk keluarga, selain menjahit beliau juga berternak dengan sistem maparo, dimana beliau mendapatkan modal berupa kambing. Beliau bekerjasama dengan Bapak Roestoyo yang adalah tetangganya, untuk melakukan kerjasama maparo. Berawal 
dari dua ekor kambing kini hasil dari bisnis maparo ini semakin berkembang, sehingga hasil dari sistem maparo ini dapat menjadi salah satu alternatif memperbaiki keadaan ekonomi keluarga, selain itu dari hasil beternak juga dapat digunakan untuk membiayai putra putrinya untuk bersekolah. Berikut pernyataan Bapak Wawien :

"Bermula dari berternak kambing adalah saya minta dibelikan kepada Pak Roestoyo yang sudah biasa melakukan maparo. Rerumputan dan tumbuhan sangatlah mudah dicari di desa kami ini, terlebih jika di musim penghujan, banyak tumbuh di samping rumah-rumah warga. Pagi hari saya cari rerumputan untuk pakan kambing, dan di siang harinya sampai laurt malam- malam saya mengerjakan pekerjaan menjahit. Alhamdulillah sekarang sudah memelihara kambing sejumlah delapan ekor jumlahnya."(Rosidah, Komunikasi Pribadi, 2021).

Selain kasus di atas, peneliti juga menjumpai kasus dimana seorang peternak yang awalnya hanya memelihara kambing miliknya sendiri, namun karena kambing yang dimiliknya semakin bertambah banyak, hingga akhirnya beliau mencari partner usaha untuk ikut memelihara ternaknya. Beliau adalah Bapak Rasqib, dimana yang sekarang beliau (Rasqib) memiliki tiga (3) partner usaha dalam memelihara ternaknya. Beliau bekerjasama dengan menggunakan "sistem maparo" kepada tetangganya yakni Bapak Rudhi, Bapak Moelyoeno dan Bapak Karsoeno. Bisa dikatakan, Bapak Rasqib merupakan salah satu contoh peternak perorangan yang diuntungkan oleh sistem maparo ini. Di satu sisi, tugas beliau memelihara ternak diringankan oleh tiga orang partner usaha yang ikut merawatkan ternaknya. Di sisi lain, beliau memperoleh pahala kebaikan ikut serta meningkatkan kesejahteraan orang di sekitarnya (tetangganya), dengan memberi peluang usaha untuk memperoleh penghasilan tambahan. Artinya, bukan karena sistem maparo yang tidak lagi menguntungkan bagi beliau, namun lebih karena jumlah ternak yang sudah melebihi kapasitas kemampuan mereka untuk memeliharanya.

Hal ini menjadi salah satu kelemahan dari usaha peternakan rakyat skala kecil. Peternak sebenarnya mampu untuk terus berkembang, bahkan dimungkinkan menjadi juragan ternak dengan keahlian beternak yang dimilikinya. Namun karena keterbatasan sumber daya manusia, kapasitas kandang yang kecil, dan cara beternak yang masih dengan sistem tradisional, menjadikan mereka sulit berkembang menjadi pengusaha ternak yang lebih besar. Kelebihan ternak biasanya hanya dijual untuk kebutuhan konsumtif seperti membeli kendaraan baru, alat komunikasi, dan sebagainya. Meskipun ada juga beberapa peternak seperti Bapak Roestoyo, yang menjual kelebihan ternaknya untuk membeli sawah, dan Bapak Tarqa yang menjual kelebihan ternaknya untuk membangun rumah.

Mengembangkan usaha di bidang peternakan tidak hanya bisa didukung oleh pemerintah, tapi juga dari masyarakat yang memiliki kelebihan dana, atau peternak yang memiliki kelebihan ternak. Seperti contohnya Bapak Riesynhan yang bekerja sebagai perangkat desa dan Bapak Roestoyo yang merupakan seorang pegawai wiraswasta, mereka yang memiliki kelebihan dana bisa mencari partner adalah sebuah usaha untuk mengembangkan bisnis peternakan. Sistem maparo memungkinkan mereka yang tidak memiliki keahlian beternak, bisa berbisnis di bidang peternakan.

Contoh lainnya adalah Bapak Rasqib seorang peternak kambing. Karena beliau memiliki banyak ternak, sehingga 
melebihi kapasitas kemampuannya untuk memelihara, beliau mencari partner bisnis yakni seorang tetangga di sekitar rumahnya untuk ikut merawat ternak miliknya. Tetangganya yang awalnya hanya bekerja sebagai petani dan buruh harian lepas, namun memiliki keahlian bertertak, diajak bekerjasama memelihara ternaknya dengan sistem maparo.

Jika banyak pemilik modal yang menginvestasikan dananya untuk usaha peternakan, atau peternak yang mengembangkan usahanya dengan kerjasama maparo, tidak menutup kemungkinan peternakan rakyat akan semakin banyak. Sehingga jika kuota daging mencukupi, diharapkan tidak terjadi lagi kelangkaan daging atau harga daging terlalu mahal.

Maparo yaitu salah satu sistem bisnis di bidang peternakan, dimana peternak berbisnis dengan pemilik modal. Sehingga Orang yang memiliki modal akan berinvestasi berupa hewan kambing, dimana nantinya saat kambing tersebut ketika sudah dewasa kemudian dapat langsung dijual, dan hasil dari penjualannya akan dibagi dengan pihak pemilik modal (Firdaus \& Rosidah,2020).

Sehingga dalam hal ini sistem maparo dapat menjadikan sebuah peningkatan ekonomi masyarakat ekonomi syariah di era 4.0 melalui sistem maparo tersebut. Dimana dalam hal ini masyarakat Muslim atau yang lebih dikenal dengan Masyarakat Ekonomi Syariah (MES) adalah organisasi nirlaba yang bertujuan guna mengembangkan serta mempercepat penerapan sistem ekonomi serta keuangan syariah khususnya di Indonesia.

\section{Meningkatkan Ekonomi Masyarakat Ekonomi Syariah di Era 4.0 Melalui Sistem Maparo}

Dalam rangka usaha dalam meningkatkan ekonomi masyarakat ekonomi syariah di era 4.0 melalui sistem maparo dimana era revolusi 4.0 menjadi tantangan tersendiri bagi Indonesia dalam mensejahterahkan ekonomi masyarakatnya perlu adanya trik market tersendiri salah satunya dengan mengembangkan ekonomi syariah Indonesia.

Hal ini sejalan dengan pendapat Ahyani \& Slamet (2021), bahwa dijelaskan dengan adanya respon dari dunia barat serta sumbangsih barat terhadap ekonomi syariah Indonesia dimaksudkan untuk merangkul ekonomi syariah Indonesia dengan tujuan utamanya adalah menguasai indo pasifik, dengan menerapkan sebuah trik market dalam sistem pasar bebas dan juga sistem kapitalis. Namun Indonesia tetap pada prinsipnya yaitu mengembangkan potensi ekonomi syariah, yang mana hal ini dikarenakan ekonomi syariah di Indonesia merupakan sebuah peluang emas dalam menuju Indonesia yang sejahtera. Selain itu ada dua sistem dalam meningkatkan ekonomi masyarakat ekonomi syariah di era 4.0 melalui sistem maparo dimana era revolusi 4.0 diantaranya melalui penerapan sistem bagi hasil dalam praktik maparo dan menerapkan prinsip yang ada pada ekonomi syariah tentang (al-ta'awun) atau prinsip tolong-menolong yang terkandung dalam kerjasama maparo. Berikut ini penjelasan terkait kedua sistem kerjasama tersebut.

\section{a. Sistem Bagi Hasil Dalam Praktik Maparo}

Ditinjau Dari Perspektif

Ekonomi Islam bahwa sistem maparo dapat dilakukan melalui distribusi pendapatan dalam sebuah kerjasama bisnis syariah dilakukan berdasarkan prinsip bagi hasil yang prosentasenya telah disepakati diawal perjanjian. Konsep bagi hasil dilakukan dalam rangka membangun kerjasama guna menaggung hasil dan resiko antara 
penanam modal dan pelaksana usaha. Sistem profit and lost sharing adalah satu dari sekian banyak konsep dalam ekonomi Islam. Sistem ini, tidak menjamin untung dari sebuah usaha. Artinya hasil dari usaha tersebut, baik itu untung atau rugi akan ditanggung oleh kedua belah pihak. Apabila usaha yang dijalankan mendapatkan hasil atau untung maka pembagian hasil atau untung sesuai dengan perjanjian yang telah dibuat dan disepekati oleh kedua belah pihak. Begitupun dalam menaggung kerugian.

Distribusi pendapatan dalam kerjasama maparo menggunakan sistem bagi hasil keuntungan penjualan indukan atau bagi hasil anakan. Bagi hasil keuntungan indukan biasanya terjadi pada kambing jantan yang dirawat sejak kecil, untuk pembagian laba dari hasil penjualan yakni sesuai kesepakatan diawal dan dikurangi dengan harga beli kambing tersebut.

Sedangkan sistem pembagian untuk kambing betina adalah bagi hasil berupa anak kambing yang dilahirkan oleh sikambing betina tersebut. Berapapun jumlah anak yang dilahirkan oleh kambing betina tersebut hasilnya akan dibagi secara merata antara pihak yang berinvestasi (penanam modal dan peternak). Jika produk dari kambing beranak dua, maka pembagiannya adalah dibagi masing-masing satu anak kambing, begitupun seterusnya.

Hal ini dikarenakan dalam menggunakan sistem bagi hasil dalam distribusi pendapatannya, maka usaha pemeliharaan ternak dengan sistem maparo inilah yang secara umum dibolehkan dalam hukum Islam. Keuntungan yang didapat oleh peternak dalam sistem maparo adalah hasil dari perputaran modal.
Untuk sistem pembagian laba dibagi sacara adil antara penanam modal dan peternak atau pelasana usaha. Begitupun jika terjadi kerugian, maka kerugiannya pun akan dibagi secara adil ( $a l^{\prime} a d l$ ) antara pihak pemilik modal dan pelaksana/pengelola usaha tersebut. Sehingga dalam hal ini dengan sistem bisnis maparo keduanya akan memiliki hak atas keuntungan ataupun kerugian yang sama, sehingga tidak menguntungkan atau merugikan salah satu pihak.

Berbicara tentang prinsip (al'adl) atau adil dalam Islam, yang mana hal ini merupakan prinsip yang memberikan keadilan antar kedua belah pihak dimana salah satu pihak tidak dirugikan atau terdzalimi. Allah Swt memerintahkan seluruh umat Islam untuk selalu berbuat adil dalam bermuamalah atau berbisnis. Sedangkan dalam arti luas, prinsip adil dapat dimaknai sebagai seimbang atau tidak berat sebelah.

Konsep adil dalam bisnis dalam hal ini yakni terdapatnya unsur gharar (manipulatif). Tidak terdapat unsur ketidakpastian dalam transaksi kerjasama maparo ternak. Yang ada adalah ketidakpastian yang umum dalam bisnis, yaitu ketidakpastian mengenai untung atau ruginya bisnis yang dijalani. Yang demikian itu bukan termasuk gharar, karena ketidakpastian tersebut merupakan salah satu resiko bisnis, yang menjadi salah satu alasan Islam mendorong umatnya untuk melakukan bisnis. Jika bisnis sudah dijamin untung sejak awal, justru kondisi yang demikian ini tidak wajar, karena kepastian untung atau rugi dalam usaha yang dijalani menjadi kehendak Allah SWT.

Kemudian dilarangnya maisir, dimana salah satu pihak diuntungkan dan salah satu pihak dirugikan. Tidak terdapat unsur maisir dalam sistem 
maparo ini, karena pemilik modal menitipkan ternaknya untuk dipelihara, sekaligus siap menanggung resiko bisnis yang akan dihadapinya termasuk hilangnya modal. Di sisi lain, pemelihara ternak sebatas memelihara ternaknya dan ternak yang dititipkan kepadanya, tidak memberikan jaminan keuntungan bisnis kepada pemodal. Dan jika terjadi kerugian, pemelihara ternak bukanlah pihak yang harus menanggung seluruh kerugian pemodal. Resiko bisnis dipikul oleh kedua belah pihak.

Selanjutnya dilarangnya tadlis, atau tidak adanya transparansi informasi antara kedua belah pihak. Dalam sistem maparo, tidak ada informasi yang disembunyikan baik oleh pemilik modal maupun pemelihara ternak. Harga beli dan harga jual ternak, kondisi perkembangan ternak, dan informasi lain mengenai usaha yang dijalankan diketahui oleh kedua belah pihak secara terbuka dan dapat diketahui kapanpun.

b. Prinsip Tolong Menolong Dalam Kerjasama Maparo

Dalam hal al-ta'awun /tolong menolong dalam pembiayaan suatu modal dalam konsep ekonomi Islam berarti semua harta yang bernilai dalam pandangan syar'i. Dimana modal meliputi semua jenis harta yang bernilai, dalam sistem ekonomi Islam, modal dikembangkan dengan tujuan agar terjadi sirkulasi dan tidak merugi, selain itu dapat bermanfaat bagi orang lain. Dalam proses pelaksanaan bisnis, Islam mengatur tekait penanaman modal dimana modal dapat berbentuk (syirkah). Selain itu modal tidak hanya berupa uang, modal juga dapat berbentuk benda lain yang dapat bermanfaat bagi penanam modal dan pelaksana usaha. Seseorang akan mengeluarkan modal yang banyak ketika akan merintis usahanya sendiri, baik modal tenaga maupun harta.

Kemudian kerjasama disini menjadi sebuah alternatif bagi seseorang, selain itu dengan kerjasama pelaksanaan usaha juga akan lebih efisien. Dengan kerjasama, secara tidak langsung penanam modal juga akan lebih ringan dalam melaksanakan bisnisnya. Kerjasama bisnis yang dapat menjadi pilihan salah satunya dalam bidang peternakan, yaitu dengan sistem maparo.

\section{Kelebihan Kerjasama Maparo}

Adapun terdapat beberapa kelebihan dari pelaksanaan kerjasama maparo yaitu:

a. Modal usaha ditanggung bersama, yakni dengan melakukan kerjasama, seseorang yang memiliki keahlian beternak namun terkendala masalah modal, atau pemilik modal yang ingin menjalankan usaha di bidang peternakan namun tidak memiliki keahlian di bidang tersebut, keduanya bisa saling melengkapi. Jadi, seseorang yang tidak memiliki keahlian beternak juga bisa melakukan usaha peternakan melalui kerjasama dengan peternak, dengan cara menitipkan ternak untuk dipelihara dengan sistem bagi hasil. Adapun modal usaha kerjasama di bidang peternakan diantaranya: memiliki lahan untuk beternak, memiliki peralatan ternak, memiliki keahlian beternak, memiliki dana untuk modal pembelian hewan ternak, dan memiliki pasar jelas untuk penjualan hewan ternak yang diproduksi. Semua modal tersebut ditanggung bersama diantara pihak yang bekerja sama.

b. Efisiensi tenaga kerja untuk 
operasional usaha, sehingga dengan pembagian peran dan tugas dalam kerjasama usaha akan meringankan kerja. Misalnya pada kerjasama usaha antara pemodal dengan peternak dengan sistem bagi hasil, tidak memerlukan karyawan dalam operasional produksinya. Satu pihak bertanggung jawab menyediakan modal hewan ternak, dan pihak lain sebagai pemelihara ternak yang bertanggung jawab merawat dan menyediakan segala kebutuhan ternak yang dipelihara. Dengan demikian tidak ada biaya upah tenaga kerja dalam operasionalnya, karena upah dihitung berdasarkan pola bagi hasil.

c. Tidak harus memiliki tempat usaha mandiri, dimana di era 4.0 yang serba digital ini dengan mengawali atau merintis sebuah usaha, seseorang memerlukan tempat usaha untuk operasionalnya. Salah satu keuntungan kerjasama adalah, saat salah satu pihak tidak memiliki tempat usaha masih bisa tetap berjalan. Misalnya seseorang yang hanya memiliki modal sejumlah uang, tanpa keahlian beternak, tanpa harus mendirikan kandang dan sebagainya, bisa melakukan usaha di bidang peternakan melalui kerjasama dengan peternak. Modal untuk melakukan kerjasama maparo berupa hewan ternak dan keahlian beternak (tenaga). Dalam kerjasama bisnis yang dijalin antara pemilik modal dan pemelihara ternak, kedua modal tersebut digabungkan sehingga usaha pemeliharaan ternak dapat berjalan dengan baik.

Modal awal adalah hewan ternak disediakan oleh pemodal untuk selanjutnya dipelihara dan dikembangkan oleh peternak. Pengembangan dan peningkatan modal dilakukan dengan cara yang halal, yakni dengan cara produksi atau investasi. Kerjasama maparo dibiayai dengan modal hewan ternak yang dibeli pemodal, bukan dengan cara yang dilarang dalam Islam seperti mencuri, merampas kepemilikan harta secara zalim, dan sebagainya. Modal usaha ini juga berupa hewan ternak kambing, yang halal untuk dimakan maupun diternakkan seperti halnya domba, kambing dan sapi. Selanjutnya, larangan pengembangan modal dengan jalan riba (apapun bentuk dan jumlahnya), yaitu pengambilan keuntungan dengan cara mengeksploitasi tenaga orang lain. Peternak sebagai pihak yang bertanggung jawab penuh dalam pemeliharaan ternak sudah dengan rela menjalankan perannya dalam kerjasama maparo tersebut. Alhasil ekonomi islam dilihat dari konsep mudharabah praktik bagi hasil ini masih belum sesuai, karena akad yang terjalin antara shahibul mal dan mudharib adalah akad lisan bukan tulisan, dan modal awal yang diberikan pemilik modal itu masih hewan ternak bukan berupa uang tunai. Waktu kerjasama praktik bagi hasil ini tidak dibatasi sehingga menimbulkan ketidak jelasan diantara kedua belah pihak (Munthe, 2018).

Alhasil tidak ada istilah mengeksploitasi tenaga peternak dalam kerjasama usaha yang dijalankan. Kemudian larangan pengembangan modal dengan jalan penipuan. Harga beli ternak, harga jual ternak, perkembangan usahanya, dan jumlah ternak yang dipelihara sudah diketahui oleh kedua belah pihak yang bekerjasama. Tidak ada unsur penipuan dalam hal ini. Prinsip keterbukaan sangat diutamakan dalam kerjasama ini, demi menjaga 
nama baik dan hubungan baik antara pemilik modal dan pemelihara ternak. Pondasi utama dari sebuah bisnis adalah modal, dimana modal usaha harus halal, kemudian wujud dan cara memperolehnya pun dengan carayang benar dan sesuai aturan agama. Pengelolaan modal dalam bisnis harus menguntungkan kedua belah pihak, atau tidak merugikan salah satu pihak dan sesuai dengan atauran atau syariat Islam.

\section{Resiko Kerjasama Melalui Sistem Maparo}

Resiko dalam sebuah bisnis adalah hal yang tidak dapat dihindarkan, setiap orang yang berbisnis harus berani mengambil dan menanggung resiko dari bisnis yang dijlankan. Resiko dari sebuah bisnis yakni untung ataupun rugi. Hal ini muncul karena ketidakpastian dari sebuah bisnis. Resiko muncul disebabkan adanya kondisi ketidakpastian dalam bisnis, sehingga ada yang menyamakan antara resiko dengan ketidakpastian. Ada begitu banyak jenis resiko yang harus dihadapi oleh setiap pebisnis, mulai dari sikap ragu, khawatir tidak laku, kehilangan dan lain sebagainya. Dengan kerjasama, resiko bisnis akan ditanggung bersama. Semua dibagi secara adil sesuai porsinya. Maka dalam hal mengatasi resiko kerjasama melalui sistem maparo pun perlu dikuasai oleh pihak pengelola dan pihak yang melakukan investasi dalam hal ternak kambing.

Hal ini pernah terjadi sekitar dua tahun yang lalu antara Bapak Roestoyo dan Bapak Wawien. Pihak pertama atau pemodal harus siap menghadapi segala resiko, dan yang paling sering adalah hilangnya modal dan bagi peternak adalah kerugian tenaga selama memelihara hewan ternak. Sebenarnya pemodal dan peternak sudah mencoba mengantisipasi segala resiko dengan hatihati. Pemodal biasanya memilih orang yang dapat dipercaya, dan bertanggungjawab serta dapat diajak bekerjasama dalam menjalankan usahanya. Dalam konteks ekonomi Islam, hal ini sering disebut pula dengan gharar dalam masalah fiqih. Gharar yaitu kerugian, dimana hal ini adalah hal yang harus dihadapi oleh sertiap pebisnis dalam menjalankan usahanaya. Salah satu keuntungan dalam bisnis Islam yakni adanya penghargaan terhadap ketidakpastian tersebut, hal ini menjauhkan riba dalam berbisnis. Karena kerjasama maparo di Desa Sadabumi dilakukan antara tetangga atau saudara, masing-masing pihak sudah mengetahui watak dari partner yang diajak bekerjasama. Seluruh narasumber yang penulis Wawancarai belum pernah ada konflik dengan pemilik modal. Pemilik modal sudah tahu benar jika peternak yang diajak bekerjasama berwatak jujur, amanah, bertanggung jawab, dan pekerja keras, sehingga diharapkan resiko bisnisnya kecil dan modalnya terus berkembang. Peternak juga mengetahui watak partner bisnisnya, sehingga bersedia bekerjasama dan saling berbagi keuntungan maupun resiko. Walaupun tidak secara tertulis, sistem maparo ini sudah diketahui oleh kedua belah pihak. Bahkan sudah menjadi hal umum dan diketahui oleh warga di Desa Sadabumi.

Maka tidak heran jika akad kerjasama maparo hanya dilakukan secara lisan. Sehingga hanya dengan modal kepercayaan saja biasanya seorang pemilik modal sudah sangat yakin melakukan kerjasama maparo dengan peternak. Namun demikian, kerjasama yang hanya dilakukan berdasarkan prinsip kepercayaan saja, memiliki banyak kelemahan dan resiko yang lebih tinggi. Kelemahan dari sistem maparo diantaranya adalah karena akad hanya secara lisan dan tidak tertulis, maka perjanjian bisa berubah sewaktu-waktu. 
Perubahan akad bisa dilakukan oleh pemilik modal maupun oleh pemelihara ternak secara sepihak. Jika demikian, prinsip toleransi dan musyawarah harus diutamakan untuk menjaga hubungan baik antara pemilik modal dengan pemelihara ternak, yang pada umumnya masih saudara atau tetangga. Prinsip berbagi resiko dalam kerjasama bisnis Islam mengedepankan toleransi dan musyawarah, begitu juga dengan kerjasama maparo ini. Ketika terjadi permasalahan dalam kerjasama maparo, semuanya dimusyawarahkan untuk mencari solusi terbaik. Dengan ini kedua belah pihak akan saling berusaha semaksimalmungkin dalam menjalankan usahanya dan siap pula menerima kemungkinan terburuk dari bisnis tersebut. Rasulullah Saw tidak melarang setiap jenis risiko. Hal yang dilarang adalah merugikan salah satu pihak dan memakan hak orang lain, seperti mencuri, maysir, riba, khianat dan lain sebagainya.

\section{Peluang Bisnis Dalam Kerjasama Maparo \\ Rata-rata jangka waktu} pemeliharaan kambing dari sejak kecil hingga siap dijual, kurang lebih delapan sampai sepuluh bulan. Kambing jantan sedikit lebih cepat dewasa dibandingkan kambing betina. Kerjasama maparo menggunakan modal awal berupa kambing dewasa jarang dilakukan, karena membutuhkan modal besar, dan memberatkan pemodal. Yang umum dilakukan adalah kerjasama maparo dengan modal anak kambing untuk dipelihara dan dikembangkan lalu dijual pada saat mendekati bulan Haji atau Dzulhijah. Kemudian peternak dipasok anak kambing lagi di bulan Dzulkaidah, sehingga mereka melakukan penjualan setahun sekali. Peluang bisnis untuk kambing jantan dan betina berbeda. Untuk kerjasama maparo kambing jantan, bagi hasilnya adalah dari laba penjualan kambing setelah dewasa.

Dalam kerjasama maparo kambing betina, biasanya target utamanya adalah dikembangbiakan lalu keuntungannya berasal dari anakannya. Sebenarnya pada kasus maparo kambing betina kedua belah pihak lebih diuntungkan, karena memperoleh pendapatan dari bagi hasil anak kambing yang lahir dan dari laba penjualan indukan kambing ketika dijual.

Secara sederhana, melakukan kerjasama maparo kambing jantan lebih menguntungkan bagi pemelihara ternak, karena nilai investasi yang lebih tinggi dan masa tunggu yang lebih singkat. Dengan modal anak kambing jantan seharga kurang lebih satu juta rupiah, dan masa tunggu kurang lebih delapan bulan, kambing sudah laku dijual dengan harga kurang lebih tiga juta rupiah. Bagi hasil yang didapat juga pasti, yaitu berupa bagi hasil dari harga jual yang dikurangi harga beli. Jika masa tunggu lebih singkat, maka resiko bisnisnya juga lebih kecil. Lain halnya untuk kerjasama maparo dengan modal anak kambing betina, dengan masa tunggu yang sama, harga jualnya lebih kecil. Jika modal awal berupa indukan betina, maka akan memberatkan pemilik modal karena harganya jauh lebih mahal meskipun masa tunggunya lebih singkat. Namun, jika pada dasarnya baik pemilik modal maupun pemelihara ternak memang sama-sama lebih menyukai "tabungan" hewan ternak, resiko maupun masa pemeliharaan ternak tidak menjadi masalah. Dalam hal ini, alasan ekonomi bukan menjadi tujuan utamanya, melainkan prinsip tolong menolong, toleransi, dan menjalin hubungan persaudaraan menjadi alasan utama beberapa pelaku maparo melakukan sistem ini.

\section{SIMPULAN}

Berdasarkan hasil penelitian diatas tentang sistem maparo yang digunakan sebagai metode atau trik market dalam 
meningkatkan ekonomi Masyarakat melalui sistem maparo ternak kambing tersebut di era 4.0 seperti sekarang ini di Desa Sadabumi Kecamatan Majenang Kabupaten Cilacap, Provinsi Jawa Tengah, maka penulis dapat mengambil kesimpulan bahwa dalam hal kerjasama peternakan kambing maparo oleh masyarakat Muslim (Masyarakat Ekonomi Syariah) yang tinggal di Desa Sadabumi termasuk kedalam akad mudharabah muqayyadah. Sistem maparo bukan sekedar bisnis, melainkan ada hal-hal lain yang tersirat didalamnya, salahsatunya adalah sebagai ajang silaturahmi. Sehingga di dalam Kerjasama antara pemodal dan peternak dalam sistem maparo adalah kegiatan gotong royong dalam membangun kerjasama dalam berbisnis dan berbagi resiko usaha. Kerjasama pemeliharaan ternak dengan sistem maparo merupakan manifestasi dari prinsip-prinsip dalam bisnis syariah, seperti keadilan, tolong menolong, dan berbagi resiko. Prinsip keadilan diterapkan dalam distribusi pendapatan yang menggunakan prinsip bagi hasil. Prinsip Al-Ta'awun (tolong menolong) menjadi modal dalam kerjasama sistem maparo. Prinsip berbagi resiko dalam bisnis syariah juga diterapkan dalam kerjasama maparo. Resiko kerjasama maparo diantaranya matinya hewan ternak, jangka waktu dalam hal pemeliharaan ternak, hewan ternak yang sakit, hingga resiko ternak yang hilang atau terkena cacat, kesemuanya ini harus ditanggung bersama antara pihak pemilik modal dan pihak pemelihara ternak tersebut sesuai kesepakatan bersama.

\section{DAFTAR RUJUKAN}

Abdul Halim Iskandar. (2021). Kementerian Desa, Pembangunan Daerah Tertinggal, dan Transmigrasi.

Ahyani, H., \& Slamet, M. (2021). Respon Dunia Barat Terhadap Ekonomi
Syariah Di Era Revolusi Industri 4.0. JPED Uurnal Perspektif Ekonomi Darussalam)(Darussalam Journal of Economic Perspectives), $7(1), 23-44$.

Arikunto, S. (2010). Prosedur Penelitian Suatu Pendekatan praktik. Jakarta: Reinika Cipta.

Badan Pusat Statistik Indonesia. (2021). Ekonomi Indonesia Triwulan I2021.

Firdaus, D. A., \& Rosidah, M. (2020). Sistem Maparo Peternakan Kambing Dalam Meningkatkan Ekonomi Masyarakat. Sebi: Studi Ekonomi Dan Bisnis Islam. Vol.2. No.2.

Khairudin, M. (2010). Praktik Bagi Hasil Nggado Sapi Di Desa Grantung Kecamatan Bayan Kabupaten Purworejo Menurut Hukum Islam. Skripsi. UIN Sunan Kalijaga Yogyakarta.

Rosidah, M (2021). Wawancara bersama Bapak Wiwien pada bulan juni 2021. Komunikasi Pribadi.

Munthe, Y. A. G. (2018). Analisis Penerapan Sistem Bagi Hasil Belah Sapi Dalam Peternakan Sapi Di Desa Lobu Rampah Kecamatan Marbau Kabupaten Labuhan Batu Utara. Skripsi. Universitas Islam Negeri Sumatera Utara Medan. 